\title{
Enhanced natural killer cell activation by exopolysaccharides derived from yogurt fermented with Lactobacillus delbrueckii ssp. bulgaricus OLL1073R-1
}

\author{
Seiya Makino,, ${ }^{* 1}$ Asako Sato, ${ }^{*}$ Ayako Goto,, Marie Nakamura, ${ }^{*}$ Miho Ogawa, ${ }^{*}$ Yoshika Chiba, ${ }^{*}$ Jun Hemmi, \\ Hiroshi Kano,* Kazuyoshi Takeda,†‡ Ko Okumura, $§ \#$ and Yukio Asami* \\ ${ }^{*}$ Food Science Research Laboratories, R\&D Division, Meiji Co. Ltd., 540 Naruda, Odawara, Kanagawa 250-0862, Japan \\ †Division of Cell Biology, Biomedical Research Center, \\ fDepartment of Biofunctional Microbiota, \\ §Atopy (Allergy) Research Center, Graduate School of Medicine, and \\ \#Department of Immunology, Juntendo University School of Medicine, Bunkyo-ku, Tokyo 113-8421, Japan
}

\begin{abstract}
Yogurt is generally recognized as a beneficial food for our health, but research into its physiological effects has focused mainly on intestinal dysfunctions such as constipation and diarrhea. We previously found yogurt fermented with Lactobacillus delbrueckii ssp. bulgaricus OLL1073R-1 (hereafter OLL1073R-1) could reduce risks of catching the common cold and flu in human trials. It was assumed that immunostimulatory exopolysaccharide (EPS) produced from OLL1073R-1 play an important role in this context. However, few studies have examined the immunostimulatory effects of traditional Bulgarian yogurts fermented with different strains of lactobacilli and their metabolites. Therefore, we screened 139 L. delbrueckii ssp. bulgaricus strains and identified OLL1073R-1 as the most robust producer of EPS. This strain was also the only strain that induced the production of IFN- $\gamma$ in vitro. Oral administration of the EPS or yogurt fermented with OLL1073R-1 and Streptococcus thermophilus OLS3059 (OLL1073R-1 yogurt) augmented natural killer (NK) cell activity and induced IFN- $\gamma$ production in spleen cells in mice, whereas 2 other yogurts fermented with other strains had no effect on NK cell activity. Cellular preparations of the OLL1073R-1 strain also slightly augmented NK cell activity, but were less effective than EPS itself. The EPS-dependent stimulation of NK cell activity was abrogated in IFN- $\gamma$ knockout mice and in myeloid differentiation factor 88 knockout mice. Furthermore, IFN- $\gamma$ production from spleen cells stimulated with EPS was completely blocked with both anti-IL-12 and anti-IL-18 antibodies in vitro. These findings suggest that NK cell activation by OLL1073R-1 yogurt is EPS-dependent, occurs via IL-12- and IL-18-mediated IFN- $\gamma$ production, and requires myeloid differentiation factor 88 . We
\end{abstract}

Received September 10, 2015.

Accepted October 14, 2015.

${ }^{1}$ Corresponding author: seiya.makino@meiji.com showed that traditional Bulgarian yogurt could exert immunostimulatory effects by selecting starter strains and part of the mechanisms depend on IFN- $\gamma$ inducible EPS produced from L. delbrueckii ssp. bulgaricus. Further investigations on processes of fermentation to increase of the EPS may lead to the development of new functional foods that keep our immune functions stable.

Key words: yogurt, exopolysaccharide, interferon- $\gamma$, natural killer

\section{INTRODUCTION}

Lactic acid bacteria have been widely used in fermented foods for thousands of years. Yogurt is possibly the most familiar fermented food worldwide, due in part to the belief that the regular consumption of yogurt was responsible for the unusually long lifespans of Bulgarian peasants (Metchnikoff, 1907). Traditional Bulgarian yogurts are made from milk by fermenting with Lactobacillus delbrueckii ssp. bulgaricus and Streptococcus thermophilus, and yogurt is currently defined in the Codex Alimentarius as a milk product obtained by fermentation of milk by the action of these 2 species (Codex Alimentarius, 2011). Yogurt promotes health by improving intestinal dysfunctions, such as the symptoms of lactose intolerance and diarrhea (Guarner et al., 2005); however, additional health benefits and their associated molecular mechanisms are relatively unexplored compared with probiotics.

Probiotics are defined as "live microorganisms, which, when administered in adequate amounts, confer a health benefit on the host" (Reid et al., 2003). Most probiotics are derived from commensal bacteria that can be found in the human large intestine, including bifidobacteria and lactic acid bacteria. These bacteria act not only on the intestine, but also on the entire body, including the immune system (Xiao et al., 2006; Takeda and Okumura, 2007), metabolism (Kadooka et al., 2013), and mental state (Tillisch et al., 2013). Some 
were reported to reduce respiratory infections duration in the elderly (Guillemard et al., 2010) or frequency in infants and children (Hatakka et al., 2001; Leyer et al., 2009; Merenstein et al., 2010).

Ingestion of yogurt fermented with L. delbrueckii ssp. bulgaricus OLL1073R-1 (OLL1073R-1) can reduce the risk of catching the common cold and flu and can augment natural killer (NK) cell activity in subjects with low NK cell activity (Makino et al., 2010). Strain OLL1073R-1, which was originally isolated from traditional Bulgarian yogurt, produces high amounts of immunostimulatory exopolysaccharide (EPS; Kitazawa et al., 1998; Nishimura-Uemura et al., 2003); we have previously shown that EPS has IFN- $\gamma$ inducing activity (Makino et al., 2006). Oral administration of the EPS derived from OLL1073R-1 and yogurt fermented with this strain enhances NK cell activity in mice (Makino et al., 2006) and exerts anti-influenza virus activity (Nagai et al., 2011). However, it remains unclear whether EPS has additional roles in the immunostimulatory effects of yogurt fermented with OLL1073R-1, and whether yogurts fermented with other strains have similar properties. Furthermore, the precise molecular mechanisms involved in the immunostimulatory effect of EPS in vivo remain unclear.

In the current study, we compared the amounts of EPS produced from 139 strains of $L$. delbrueckii ssp. bulgaricus and evaluated the ability of purified EPS to induce IFN- $\gamma$. We also studied the contribution of cytokines, such as IFN- $\gamma$, IL-12, IL-18, and the signal transduction molecule myeloid differentiation factor 88 (MyD88), on EPS-dependent activation of NK cells. We found differences between these strains in terms of EPS production, IFN- $\gamma$-inducing abilities, and NK cell activation. Molecular profiling revealed that NK cell activation required IL-12- and IL-18-dependent IFN- $\gamma$ induction, which in turn operated via MyD88-driven signaling.

\section{MATERIALS AND METHODS}

\section{Mice}

$\mathrm{C} 3 \mathrm{H} / \mathrm{HeJ}$ mice were purchased from Japan SLC Inc. (Hamamatsu, Japan). BALB/c mice were purchased from CLEA Japan Inc. (Tokyo, Japan). Iterferon- $\gamma$ knockout (KO) mice on a BALB/c background were supplied from Juntendo University School of Medicine. Myeloid differentiation factor $88 \mathrm{KO}$ mice on a BALB/c background were obtained from Oriental Bioservice (Kyoto, Japan). All mice were obtained at 7 wk of age and acclimatized for $1 \mathrm{wk}$. Mice were housed at 23 to $25^{\circ} \mathrm{C}$ with a 12 -h light/dark cycle and supplied with a commercial diet (Oriental Yeast, Tokyo, Japan) and tap water ad libitum. All animal experiments were performed according to the guidelines of the Ethical Committee for animal experiments of Meiji Co., Ltd.

\section{Microorganisms and Culture}

Lactobacillus delbrueckii ssp. bulgaricus strains ( $\mathrm{n}=$ 139) originating from traditional Bulgarian yogurts and native plants in Bulgaria (Michaylova et al., 2007) were each subcultured twice at $37^{\circ} \mathrm{C}$ for $18 \mathrm{~h}$ in $10 \%$ (wt/wt) skim milk (SM). The preculture was inoculated (1\%, wt/wt) into fresh $10 \%$ (wt/wt) SM and incubated at $37^{\circ} \mathrm{C}$ for $18 \mathrm{~h}$ to purify EPS and measure their amounts.

Strain OLL1073R-1 was cultured in de Man, Rogosa, Sharpe broth (Becton Dickinson, Sparks, MD) at $37^{\circ} \mathrm{C}$ for $18 \mathrm{~h}$ once a week to obtain live and heat-killed bacterial cells for oral administration to mice. The cultures were centrifuged at $10,000 \times g$ at $4^{\circ} \mathrm{C}$ for $15 \mathrm{~min}$ and the collected live bacterial cells were suspended in saline at $2.5 \times 10^{9} \mathrm{cfu} / \mathrm{mL}$ after washing twice. Inactivation of bacterial cells was performed by heating live cell suspensions at $75^{\circ} \mathrm{C}$ for $1 \mathrm{~h}$. Live and heat-inactivated cells were preserved at $4^{\circ} \mathrm{C}$ until oral administration to mice.

Yogurts were prepared using a laboratory-scale manufacturing process. Starter cultures contained $L$. delbrueckii ssp. bulgaricus OLL1073R-1 and S. thermophilus OLS3059 (OLL1073R-1 yogurt), L. delbrueckii ssp. bulgaricus OLL1245 and S. thermophilus OLS3059 (yogurt A), and L. delbrueckii ssp. bulgaricus OLL1256 and S. thermophilus OLS3295 (yogurt B). After pasteurization of $10 \%$ (wt/wt) SM by heating to $90^{\circ} \mathrm{C}$ and immediate cooling to $45^{\circ} \mathrm{C}$, the $\mathrm{SM}$ was inoculated with $1 \%$ (wt/wt) of each yogurt starter culture. The cultures were allowed to ferment at $43^{\circ} \mathrm{C}$ for $4 \mathrm{~h}$, with fermentation being halted by cooling. The acidity of each culture ranged from 0.84 to $0.88 \%$.

\section{Purification of EPS}

The cultures of L. bulgaricus strains or yogurts were mixed with 100\% (wt/wt) trichloroacetic acid (Wako, Tokyo, Japan) to a concentration of $10 \%$ (wt/wt) and centrifuged at $12,000 \times \mathrm{g}$ at $4^{\circ} \mathrm{C}$ for $20 \mathrm{~min}$. The culture supernatants were mixed with 2 volumes of ethanol (Wako) and incubated overnight at $4^{\circ} \mathrm{C}$. The solutions were centrifuged at $12,000 \times g$ at $4^{\circ} \mathrm{C}$ for 20 min and the pellets were dissolved in MilliQ (Millipore, Billerica, MA) water (crude EPS solution). After dialyzing against MilliQ water, crude EPS solutions were incubated at $37^{\circ} \mathrm{C}$ with DNase (EC 3.1.21.1; Sigma Aldrich, St. Louis, MO), RNase (type I-AS, EC 3.1.27.5; Sigma Aldrich), and proteinase K (EC 3.4.21.64; Sigma Aldrich), as described previously (Makino et al., 2006). 
The enzymes were subsequently inactivated by heating at $90^{\circ} \mathrm{C}$ for $10 \mathrm{~min}$. Each solution was mixed with 2 volumes of ethanol, incubated overnight at $4^{\circ} \mathrm{C}$, and centrifuged, as described previously. The EPS was dissolved in and dialyzed against MilliQ water using a dialysis membrane (molecular weight cutoff 6,000-8,000; Spectrum Laboratories Inc., Rancho Dominguez, CA) and lyophilized.

Exopolysaccharide purified from OLL1073R-1 cultures was dissolved in $0.02 M$ Tris- $\mathrm{HCl}$ buffer ( $\mathrm{pH}$ 8.6) and fractionated into neutral EPS (NPS) and acidic EPS (APS) by DEAE Sepharose Fast Flow (GE Healthcare, Little Chalfont, UK). The NPS were obtained as the flow-through fraction, and APS were obtained as the fraction that was eluted with $0.5 \mathrm{M}$ $\mathrm{NaCl}$. Each fraction was then lyophilized after ethanol precipitation and dialysis, as described previously. To estimate the amounts of EPS in the crude EPS solutions, the latter were dialyzed against MilliQ water using a 96-well dialyzer (molecular weight cutoff 5,000; Harvard Apparatus, Holliston, MA), and the EPS concentrations were measured using a phenol-sulfuric acid method (Dubois et al., 1956).

\section{Cell Culture}

Mice spleen cells were cultured at $5 \times 10^{5}$ cells/well in 96-well plates (Corning, Corning, NY) at $37^{\circ} \mathrm{C}$ in a $5 \% \mathrm{CO}_{2}$ atmosphere in RPMI 1640 medium, which contained $25 \mathrm{mM}$ HEPES, $300 \mathrm{mg} / \mathrm{L}$ of L-glutamine, $10 \%$ fetal bovine serum, $1 \%$ penicillin-streptomycin, and 5.5 $\mu M$ 2-mercaptoethanol (Becton Dickinson).

Spleen cells from male $\mathrm{C} 3 \mathrm{H} / \mathrm{HeJ}$ mice were suspended in RPMI 1640 medium and incubated for $72 \mathrm{~h}$ in the presence of EPS, NPS, or APS $(100 \mu \mathrm{g} / \mathrm{mL}$ final concentration). For the neutralizing antibody assay, spleen cells and APS were incubated with or without $10 \mu \mathrm{g} /$ $\mathrm{mL}$ of anti-mouse IL-12 (p40/p70; Becton Dickinson), anti-mouse IL-18 (Becton Dickinson), or both. Spleen cells from mice administered yogurts, EPS, or bacterial cells were suspended in RPMI 1640 medium and incubated with $1 \mu \mathrm{g} / \mathrm{mL}$ of anti-mouse CD3e (eBioscience, San Diego, CA) for $48 \mathrm{~h}$.

\section{Oral Administration}

Fifty female BALB/c mice were divided into 5 groups and administered $0.4 \mathrm{~mL}$ of distilled water (DW), $10 \%$ SM, OLL1073R-1 yogurt, yogurt A, or yogurt B once daily for 3 wk via oral gavage. Forty female BALB/c mice were divided into 4 groups and administered 0.4 $\mathrm{mL}$ of DW, $1 \times 10^{9} \mathrm{cfu}$ of live or heat-killed OLL1073R-1 bacterial cells, or $100 \mu \mathrm{g}$ of EPS purified from a culture of OLL1073R-1 once daily for 3 wk via oral gavage.
Twenty female wild-type (WT) BALB/c mice or female IFN- $\gamma \mathrm{KO}$ mice were divided into 2 groups, with one being administered $0.4 \mathrm{~mL}$ of $\mathrm{DW}$ and the other being administered OLL1073R-1 yogurt or $100 \mu \mathrm{g}$ of EPS purified from a culture of OLL1073R-1 once daily for 3 wk via oral gavage. Twenty male WT BALB/c mice or male MyD88 KO mice were divided into 2 groups, with one being administered $0.4 \mathrm{~mL}$ of $\mathrm{DW}$ and the other being administered $100 \mu \mathrm{g}$ of EPS once daily for $3 \mathrm{wk}$ via oral gavage.

\section{NK Cell Activity}

The NK cell activity of spleen cells was determined using standard $4-\mathrm{h}{ }^{51} \mathrm{Cr}$ release assays (Takeda et al., 1996). Briefly, spleen cells were incubated at a 200:1 ratio with ${ }^{51} \mathrm{Cr}$-labeled YAC-1 cells in 96-well roundbottom microtiter plates for $4 \mathrm{~h}$. The supernatants were harvested and their radioactivity counted using a gamma counter. Cytotoxicity was calculated as the percentage of released counts after subtracting counts released in the absence of spleen cells (spontaneous release).

\section{Cytokine Assays}

The concentrations of IFN- $\gamma$, IL-4, IL-6, and IL-10 in the culture supernatants were analyzed using OptEIA ELISA kits (Becton Dickinson).

\section{Statistical Analysis}

Experimental data were expressed as means and their standard deviations evaluated using Student's $t$ tests and one-way ANOVA, followed by Dunnett's or the Tukey-Kramer post hoc test. All analyses were performed using StatView 5.0 software (Abacus Concept Inc., Berkeley, CA), with a $P$-value $<0.05$ being considered significant.

\section{RESULTS}

\section{Selection of Strains Producing EPS and Evaluation of IFN-y Induction}

We first screened 139 strains of L. bulgaricus for EPS production, which we found varied considerably (Figure 1A). From cultures of the top 10 strains, we purified EPS and determined the amount following lyophilization. This revealed that only 3 strains (OLL1073R-1, $L$. bulgaricus OLL1251, and L. bulgaricus OLL1247) produced more than $100 \mathrm{mg} / \mathrm{kg}$ of EPS, with OLL1073R-1 being the highest EPS producer $(154.6 \mathrm{mg} / \mathrm{kg}$; Figure 1B). Among them, only EPS derived from OLL1073R-1 
A)

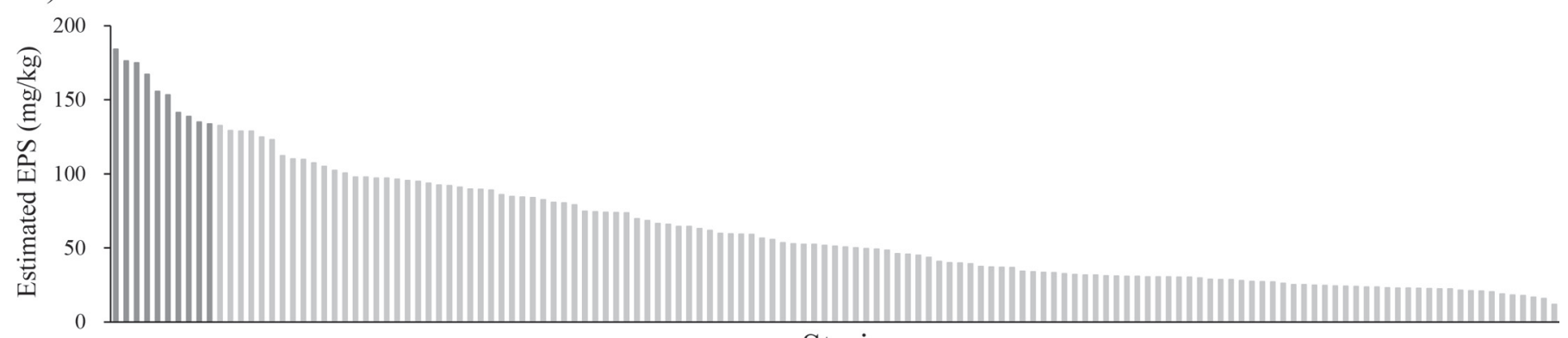

Strains
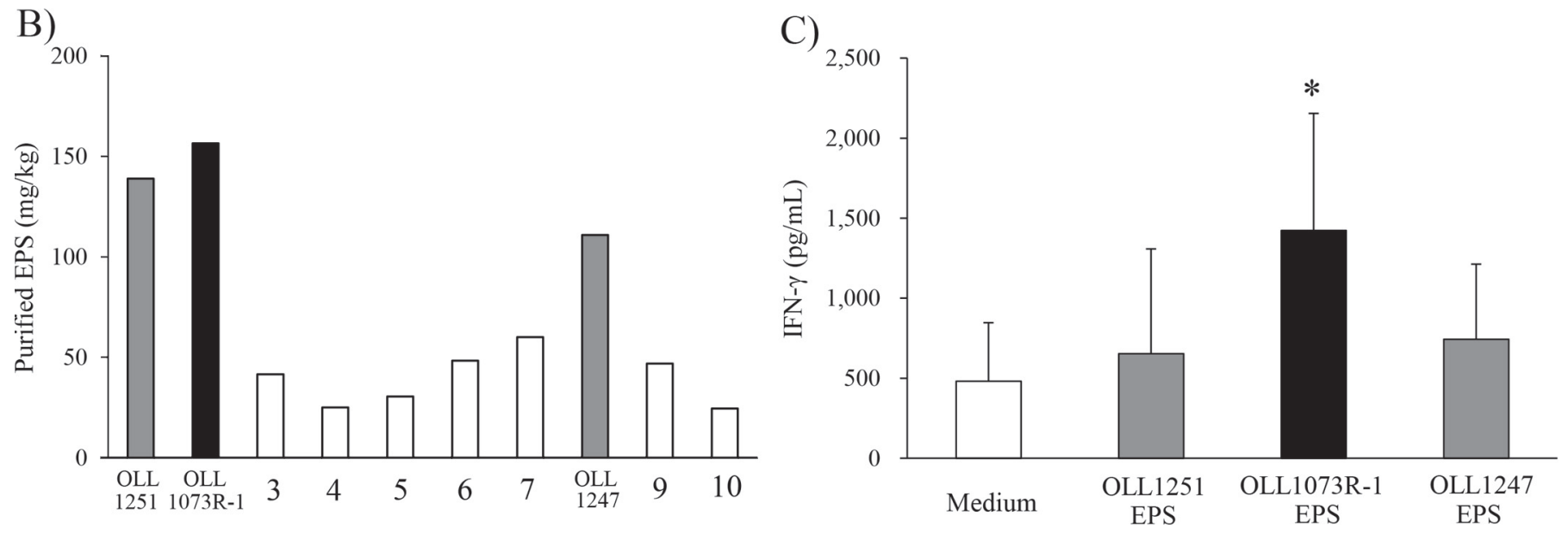

Figure 1. Estimation of the amounts of exopolysaccharide (EPS) produced by the 139 Lactobacillus delbrueckii ssp. bulgaricus strains using the phenol-sulfuric acid method (A) and the amounts of EPS purified from the cultures of the top 10 strains (B). Murine splenic cell IFN- $\gamma$ production stimulated by EPS from strains producing over $100 \mathrm{mg} / \mathrm{kg}(\mathrm{C})$. An asterisk $(*)$ represents significant difference $(P<0.05)$ compared with medium alone using Dunnett's multiple comparison test. Error bars represent the SD for 6 measurements.

was capable of eliciting IFN- $\gamma$ production from mice spleen cells in vitro (Figure 1C).

\section{Production of Cytokines upon Stimulation with EPS}

We used an in vitro cytokine-production assay to compare the immunostimulatory properties of EPS purified from 3 different yogurts (OLL1073R-1 yogurt, yogurt A, and yogurt B). A significant increase of IFN- $\gamma$ production was observed following stimulation with EPS purified from the OLL1073R-1 yogurt, but not with EPS purified from either of the other yogurts (Figure 2A). Although variable, an increased production of IL-6 and IL-10 was detected following treatment with all EPS samples (Figure 2B, C).

\section{Increased NK Cell Activity and IFN-y Production}

We examined NK cell activity and cytokine production in murine spleen cells after oral administration of the OLL1073R-1 yogurt, yogurt A, or yogurt B. A sig- nificant increase of NK cell activity was detected only in mice administered the OLL1073R-1 yogurt (Figure 3). In mice administered the OLL1073R-1 yogurt, splenic cell IFN- $\gamma$ production was significantly greater compared with mice administered DW but not SM (Figure 4A). By contrast, no significant difference was noted between the DW group and yogurt A- or yogurt B-treated groups. No significant differences in IL-4, IL6 , and IL-10 production were observed between groups (Figure 4B-D).

\section{Increased NK Cell Activity and IFN-Y Production after Treatment}

The OLL1073R-1 yogurt contained EPS and the bacterial cells of OLL1073R-1 at concentrations of 41.5 $\mu \mathrm{g} / \mathrm{g}$ and $3.5 \times 10^{8} \mathrm{cfu} / \mathrm{g}$, respectively. Therefore, we administered EPS or bacterial cells to mice at doses of $100 \mathrm{\mu g} /$ mouse and $10^{9} \mathrm{cfu} /$ mouse, respectively; doses equivalent to $\sim 2.4$ to $2.9 \mathrm{~g}$ of yogurt. The NK cell activity in the EPS-treated group markedly increased in 
A)

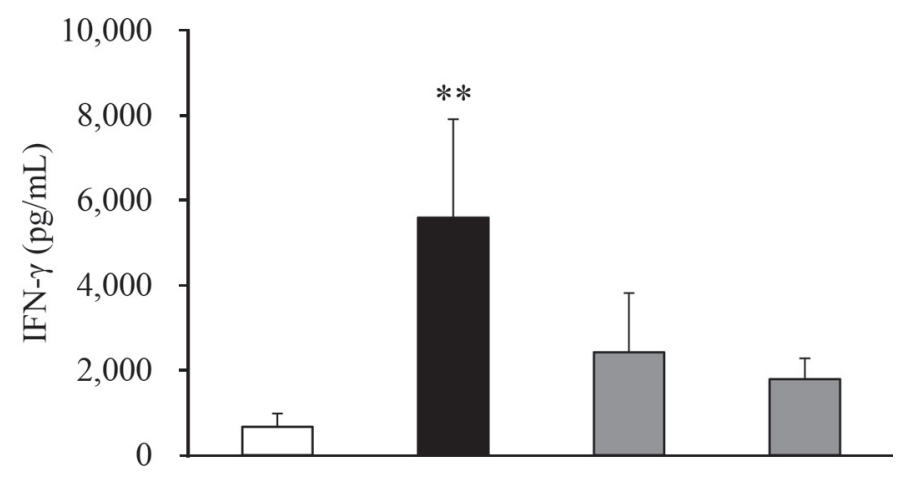

B)

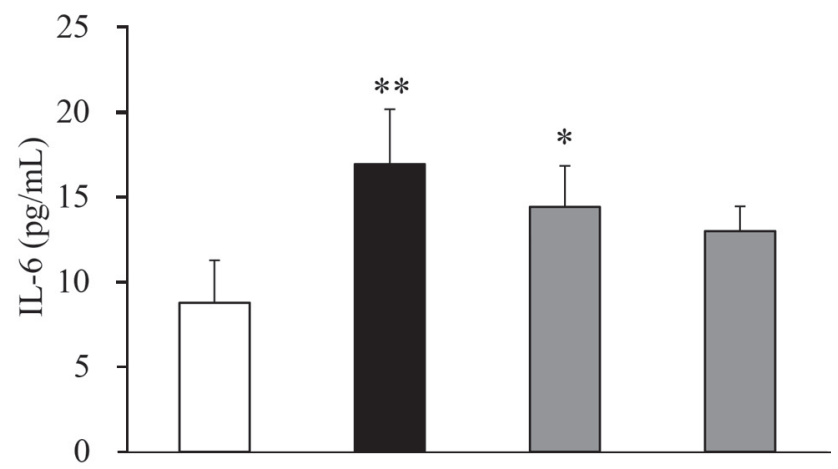

C)

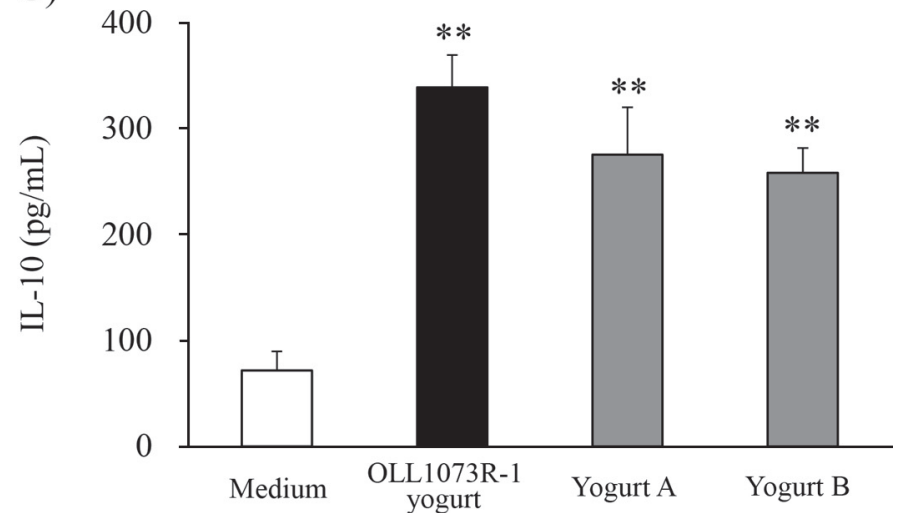

Figure 2. Interferon- $\gamma$ (A), IL-6 (B), and IL-10 (C) production from mouse spleen cells stimulated by exopolysaccharide purified from yogurts fermented with different strains of Lactobacillus delbrueckii ssp. bulgaricus. OLL1073R-1 yogurt was fermented with L. bulgaricus OLL1073R-1 and Streptococcus thermophilus OLS3059. Yogurt A was fermented with $L$. bulgaricus OLL1245 and S. thermophilus OLS3059. Yogurt B was fermented with L. bulgaricus OLL1256 and S. thermophilus OLS3295. A single $(*)$ or double asterisk $\left(^{* *}\right)$ represents significant difference $(P<0.05$ and $P<0.01$, respectively) compared with medium alone, using Dunnett's multiple comparison test. Error bars represent the SD for 6 measurements.

comparison with the control group. The bacterial cells of OLL1073R-1, regardless of whether they were live or heat-killed, also augmented NK cell activity compared with saline, but the effects were significantly lower than those observed with EPS (Figure 5A). Increased splenic cell IFN- $\gamma$ production was detected in mice administered EPS, but not in those treated with bacterial cells (Figure 5B).

\section{Enhanced NK Cell Activity Requires IFN- $y$ and MyD88}

To confirm the involvement of IFN- $\gamma$ in the activation of NK cells by OLL1073R-1 yogurt and EPS in vivo, we investigated effect of OLL1073R-1 yogurt and EPS on NK cell activity in IFN- $\gamma$ KO mice. In WT mice, NK cell activity was increased significantly by oral administration of both OLL1073R-1 yogurt and EPS, whereas no increases were observed in IFN- $\gamma \mathrm{KO}$ mice (Figure 6A, B). We also investigated the involvement of the signal transduction molecule, MyD88. As observed in IFN- $\gamma \mathrm{KO}$ mice, the EPS-dependent increase in NK cell activity was attenuated in MyD88 KO mice (Figure $6 \mathrm{C})$.

\section{IL-12 and IL-18 Are Required for IFN-y Induction}

We previously showed that OLL1073R-1 EPS could be divided into NPS and APS subtypes, and that APS exerted IFN- $\gamma$-inducing activity (Makino et al., 2006). We confirmed this in the current study, as only APS stimulated the production of IFN- $\gamma$ by murine splenic cells in vitro (Figure 7A). Addition of anti-IL-12 monoclonal antibodies $(\mathbf{m A b})$ reduced, but did not completely block, APS-dependent IFN- $\gamma$ production (Fig-

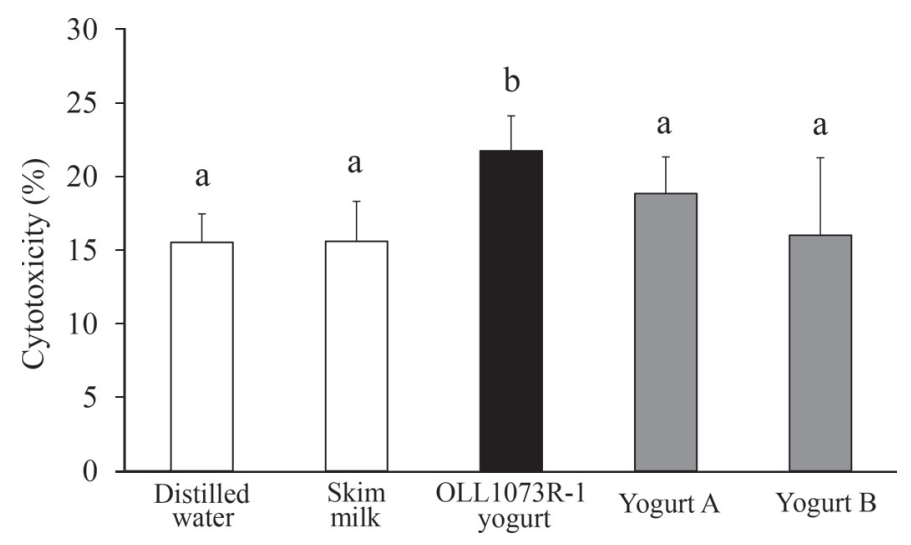

Figure 3. Natural killer cell activity of murine splenic cells treated with skim milk and 3 yogurts fermented with different strains of Lactobacillus delbrueckii ssp. bulgaricus. OLL1073R-1 yogurt was fermented with L. bulgaricus OLL1073R-1 and Streptococcus thermophilus OLS3059. Yogurt A was fermented with L. bulgaricus OLL1245 and S. thermophilus OLS3059. Yogurt B was fermented with L. bulgaricus OLL1256 and S. thermophilus OLS3295. The different letters $(\mathrm{a}, \mathrm{b})$ denote significant differences between groups by Tukey's multiple comparison test $(P<0.05)$. Error bars represent SD for 10 individual mice. 
ure 7B). Although anti-IL-18 mAb also reduced IFN- $\gamma$ production, the effect was lower than that observed with anti-IL-12 mAb (Figure 7B). Complete inhibition of APS-dependent IFN- $\gamma$ induction was observed when splenic cells were incubated with both anti-IL-12 mAb and anti-IL-18 mAb (Figure 7B).

\section{DISCUSSION}

We demonstrated that EPS production varies among strains of L. bulgaricus, and that OLL1073R-1 produces the highest amounts of EPS among the tested strains. Furthermore, EPS derived from OLL1073R-1 specifically induces IFN- $\gamma$ production by splenocytes, at least in the tested L. bulgaricus strains. This specific EPS, and yogurt fermented with OLL1073R-1 (but not other
2 yogurts which contained nonimmunostimulatory EPS), increased NK cell activity and IFN- $\gamma$ production in mice. We inferred that OLL1073R-1, rather than S. thermophilus OLS3059, was the source of immunostimulatory effects. This is because yogurt A, which also contains $S$. thermophilus OLS3059, exerted no immunostimulatory activity. These results indicate that immunostimulatory properties of yogurts, at least augmentation of NK cell activity and of IFN- $\gamma$ production, are dependent on the specific starter bacterial strains or the metabolites they produce. In OLL1073R-1 yogurt, EPS-dependent production of IFN- $\gamma$ likely contributed to increased NK cell activity, because the effects of OLL1073R-1 cells alone were weaker than those observed with the EPS. A central role of IFN- $\gamma$ in EPS-dependent NK cell activation is supported by
A)

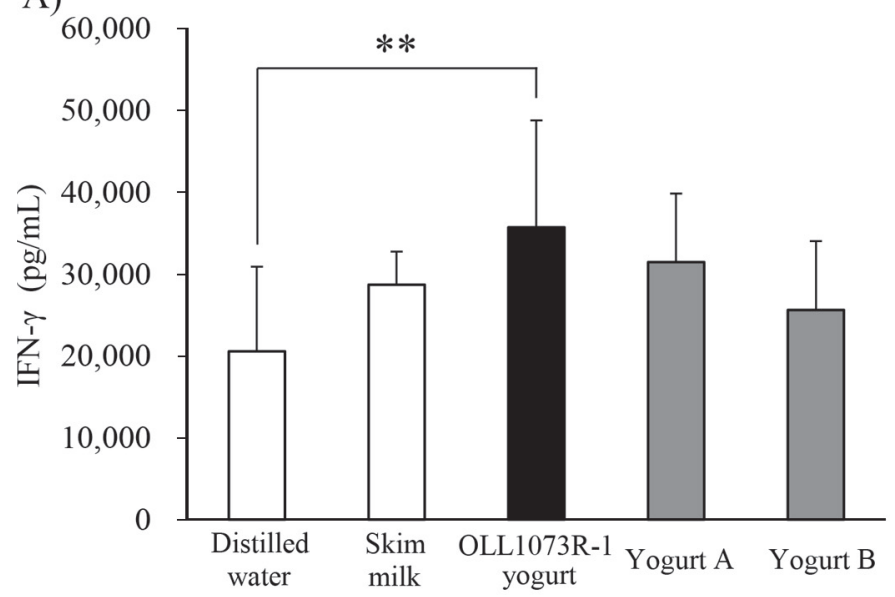

C)

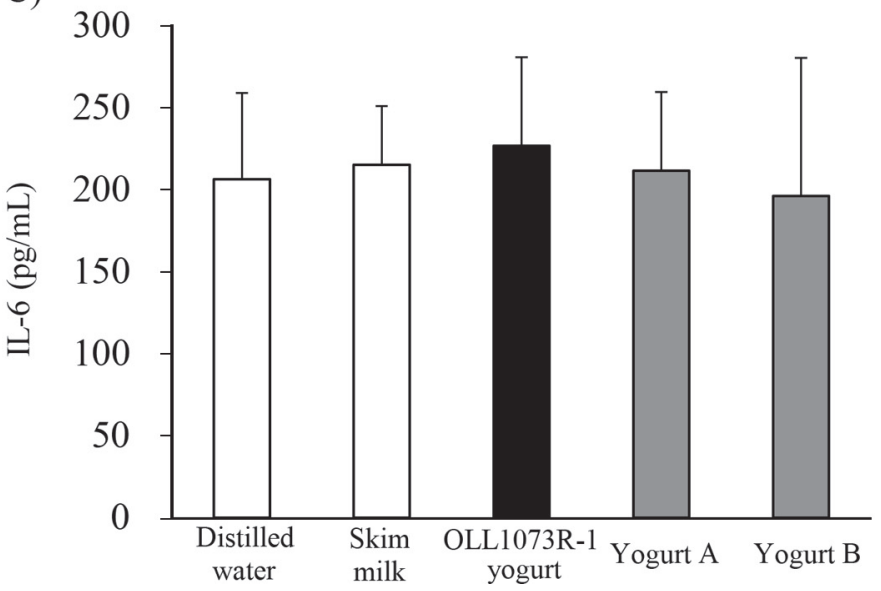

B)

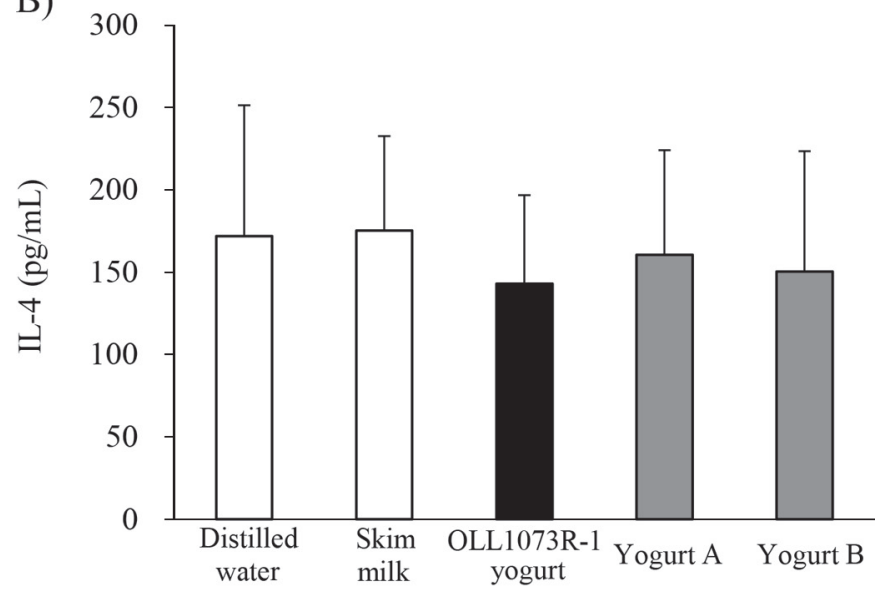

D)

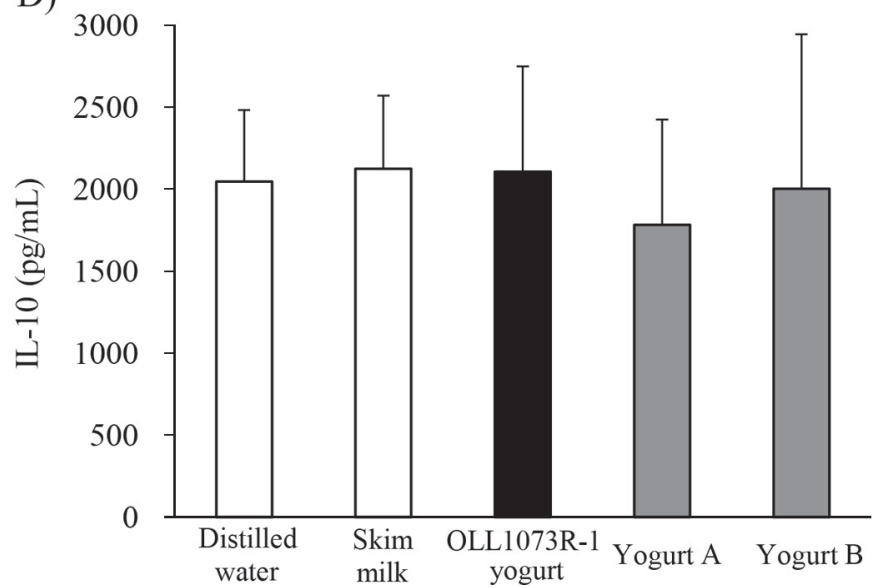

Figure 4. Interferon- $\gamma$ (A), IL-4 (B), IL-6 (C), and IL-10 (D) production from murine splenic cells treated with skim milk and 3 yogurts fermented with different strains of Lactobacillus delbrueckii ssp. bulgaricus. OLL1073R-1 yogurt was fermented with L. bulgaricus OLL1073R-1 and Streptococcus thermophilus OLS3059. Yogurt A was fermented with L. bulgaricus OLL1245 and S. thermophilus OLS3059. Yogurt B was fermented with L. bulgaricus OLL1256 and S. thermophilus OLS3295. Splenic cells were incubated for $48 \mathrm{~h}$ with the anti-CD3 monoclonal antibody. A double asterisk $\left.{ }^{* *}\right)$ represents significant difference $(P<0.01)$ by Tukey's multiple comparison test. Error bars represent SD for 10 individual mice. 
our observation that increases of NK cell activity by OLL1073R-1 yogurt and EPS were not observed in IFN- $\gamma \mathrm{KO}$ mice.

To investigate the mechanisms by which EPS is recognized by immune cells, we studied the immunostimulatory effect of EPS in MyD88 KO mice. As observed for the IFN- $\gamma \mathrm{KO}$ animals, EPS-dependent NK cell activation was not observed in MyD88 KO mice. Myeloid differentiation factor 88 is an important adapter molecule in toll-like receptor (TLR) signal transduction pathways; thus, it plays an essential role in the detection and elimination of invading microbes. MyD88 KO mice are unresponsive to ligands for TLR-2, TLR-4, TLR-5, TLR-7, and TLR-9 (O'Neill and Bowie, 2007). Additionally, phosphopolysaccharide from Lactococcus

A)

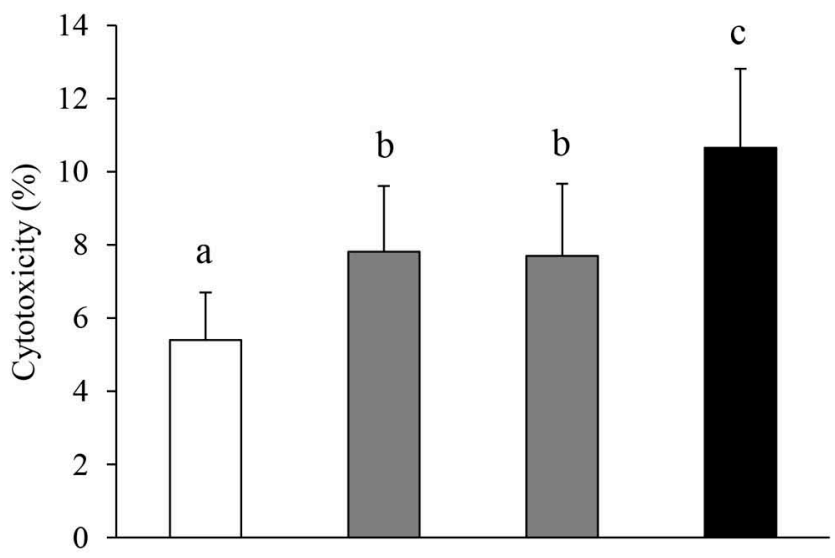

B)

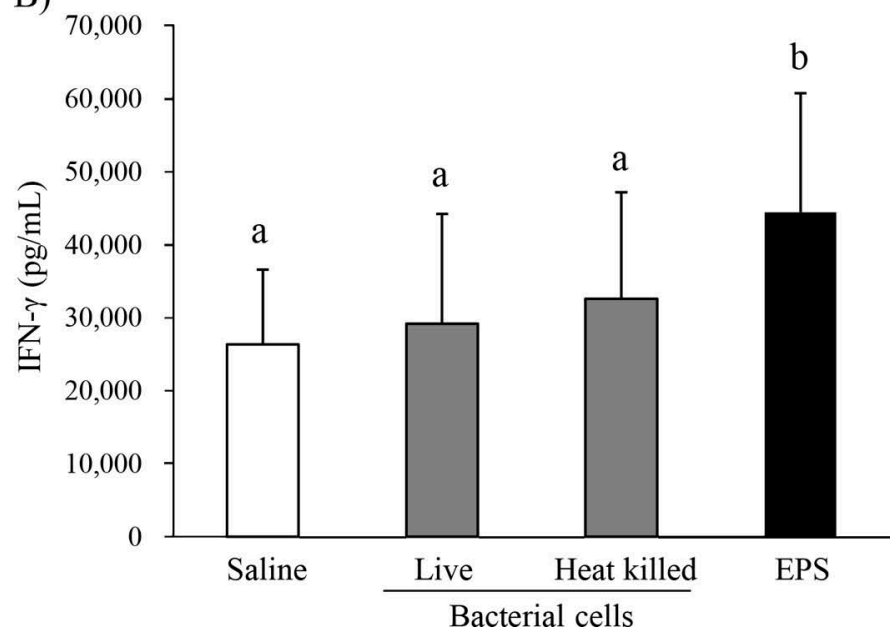

Figure 5. Natural killer cell activity of murine splenic cells after administration of Lactobacillus delbrueckii ssp. bulgaricus OLL1073R-1 cells or exopolysaccharide (EPS) produced by this strain (A). Interferon- $\gamma$ production from murine splenic cells after $48 \mathrm{~h}$ of incubation with the anti-CD3 monoclonal antibody (B). Different letters $(\mathrm{a}-\mathrm{c})$ denote significant differences between groups as determined by Tukey's multiple comparison test $(P<0.05)$. Error bars represent SD for 10 individual mice.
A)

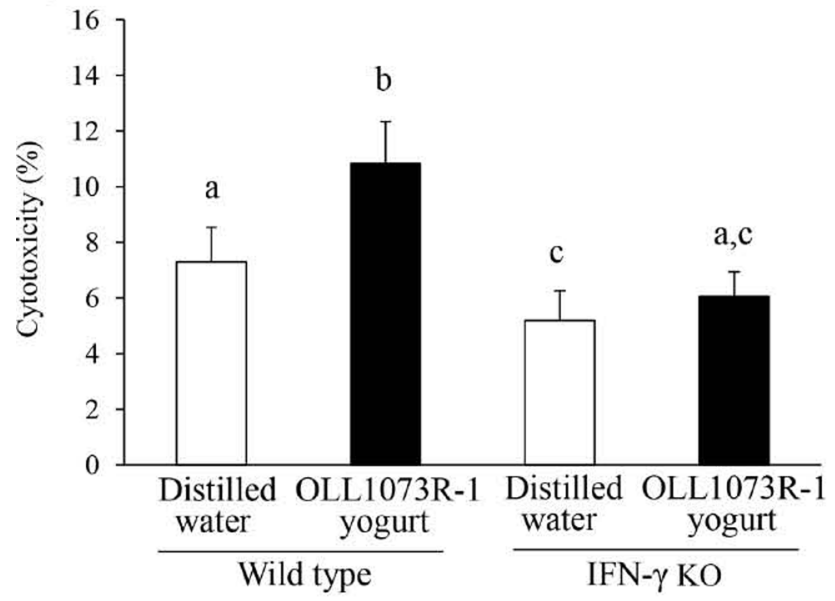

B)

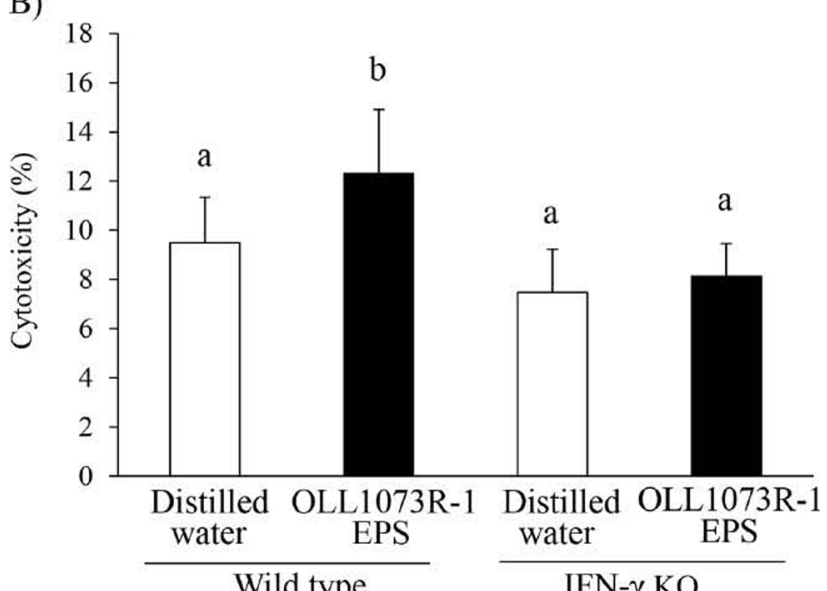

C)

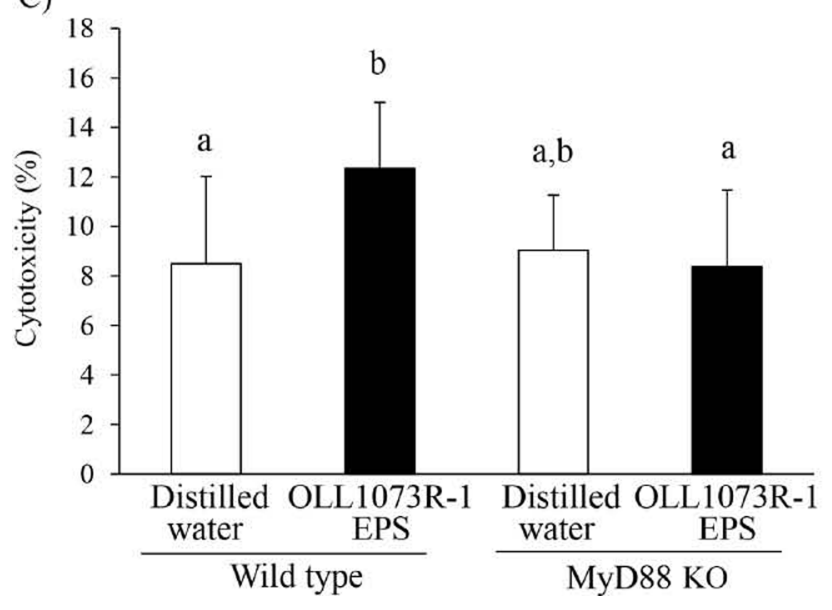

Figure 6. Natural killer cell activity of spleen cells of IFN- $\gamma$ knockout (KO) mice and myeloid differentiation factor 88 (MyD88) KO mice administered OLL1073R-1 yogurt or exopolysaccharide (EPS) produced by strain Lactobacillus delbrueckii ssp. bulgaricus OLL1073R-1. OLL1073R-1 yogurt was fermented with Lactobacillus delbrueckii ssp. bulgaricus OLL1073R-1 and Streptococcus thermophilus OLS3059. Different letters $(\mathrm{a}-\mathrm{c})$ denote significant differences between groups as determined by Tukey's multiple comparison test $(P<0.05)$. Error bars represent SD for 10 individual mice. 
A)

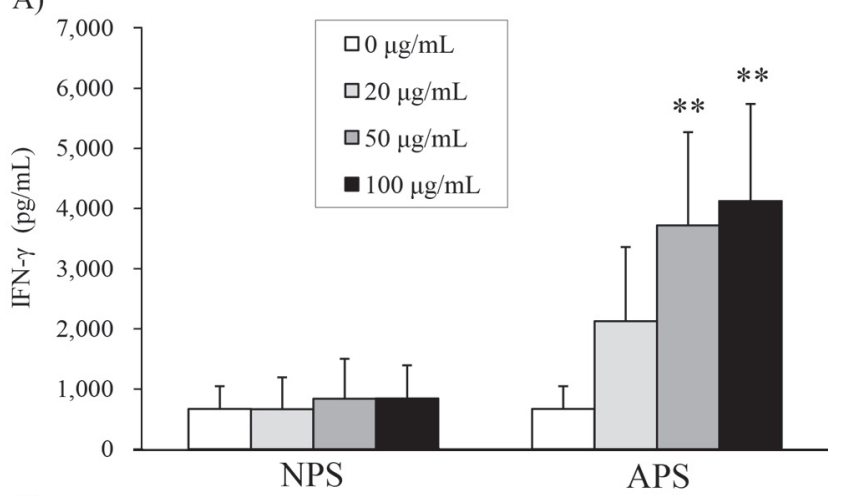

B)

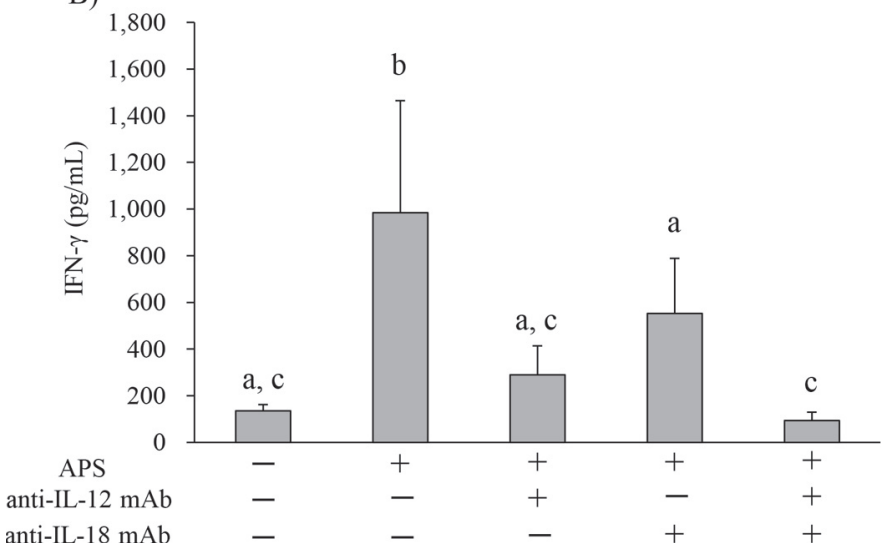

Figure 7. Interferon- $\gamma$ production from murine splenic cells stimulated by neutral exopolysaccharides (NPS) and acidic exopolysaccharide (APS) produced by Lactobacillus delbrueckii ssp. bulgaricus OLL1073R-1 (A) and the effects of anti-IL-12 monoclonal antibodies $(\mathrm{mAb})$ and anti-IL-18 $\mathrm{mAb}$ on IFN- $\gamma$ production $(\mathrm{B})$. A double asterisk $(* *)$ represents significant difference $(P<0.01)$ from $0 \mu \mathrm{g} / \mathrm{mL}$ using Dunnett's multiple comparison test. Different letters $(\mathrm{a}-\mathrm{c}) \mathrm{de}-$ note significant differences between groups as determined by Tukey's multiple comparison test $(P<0.05)$. Error bars represent the SD for 6 measurements.

lactis ssp. cremoris is recognized by the TLR homolog, RP105 (Tohno et al., 2007). Exopolysaccharide from OLL1073R-1 might therefore be recognized by pattern recognition receptors such as TLR or their homologs. However, further investigations are needed to clarify the mechanisms by which EPS is recognized by immune cells.

Pattern recognition receptors, such as TLR, are expressed mainly in innate immune cells such as dendritic cells (DC) and macrophages (Takeda et al., 2003). Direct interactions between intestinal immune cells and bacterial cells have been shown in several studies (Coombes and Powrie, 2008; Hiramatsu et al., 2011). Therefore, we inferred that orally administered OLL1073R-1 EPS was detected by DC and macrophages located beneath intestinal epithelial cells. In support of this hypothesis, we observed that OLL1073R-1 APS stimulated the secretion of IL-12 from murine bone marrow-derived
DC (data not shown). Alternatively, it is possible that immune cells in the lamina propria were indirectly affected by intestinal epithelial cells that had been stimulated by EPS. This would be consistent with results from Kishimoto et al. (2015), who showed that certain EPS molecules purified from cultures of L. delbrueckii ssp. bulgaricus strains stimulate murine macrophage RAW264.1 cells both directly and indirectly.

Interleukin-12 plays critical roles in the differentiation of CD4 T cells into IFN- $\gamma$-producing Th1 cells, as well as in the activation of NK cells to produce IFN- $\gamma$, which enhances their cytotoxic activity (Trinchieri, 2003; Watford et al., 2003). We also observed that anti-IL-12 mAb dramatically decreased IFN- $\gamma$ production in splenic cells stimulated by APS. Furthermore, responses were completely inhibited when anti-IL-12 $\mathrm{mAb}$ and anti-IL-18 mAb were used in combination. Interleukin-12- and IL-18-dependent IFN- $\gamma$ production from spleen cells stimulated by extracts of the mushroom, Agaricus blazei Murill, actually increased NK cell activity through IL-12-mediated IFN- $\gamma$ production (Yuminamochi et al., 2007). Interleukin-18 can synergize with IL-12 to induce the development of Th1 cells and activate NK cells independently of IL-12 (Okamura et al., 1998). In a manner analogous to that elicited by glucans produced by $A$. blazei, it is likely that EPS derived from OLL1073R-1 activates NK cells through both IL-12 and IL-18 signaling pathways. However, it remains unclear how EPS-dependent activation of immune cells in the intestinal tissue leads to systemic changes to the immune system (such as an increase of NK cell activity of spleen cells, for example). Future studies should examine the changes in IL-12 or IFN- $\gamma$ production from immune cells, as well as subpopulations of cells in the lymphoid tissue of intestine and spleen after oral administration of EPS.

In conclusion, we found that EPS plays important roles with regard to not only the quality and taste of yogurt, but also with respect to organismal health. These findings provide novel insight into the healthpromoting effects of yogurt fermented with $L$. bulgaricus OLL1073R-1. Investigations of the fermentation process focused on the substantial increase of immunostimulatory EPS production in yogurt may lead to the future development of yogurt with enhanced immunostimulatory properties.

\section{ACKNOWLEDGMENTS}

This study was funded by Meiji Co. Ltd. (Tokyo, Japan). The authors thank Haruki Kitazawa (Tohoku University, Sendai, Japan) for reviewing the manuscript and for his helpful comments. 


\section{REFERENCES}

Codex Alimentarius. 2011. Milk and Milk Products. 2nd ed. FAO/ OMS, Rome, Italy.

Coombes, J. L., and F. Powrie. 2008. Dendritic cells in intestinal immune regulation. Nat. Rev. Immunol. 8:435-446.

Dubois, M., K. A. Gilles, J. K. Hamilton, P. A. Rebrs, and F. Smith. 1956. Colorimetric method for determination of sugars and related substances. Anal. Chem. 28:350-356.

Guarner, F., G. Perdigon, G. Corthier, S. Salminen, B. Koletzko, and L. Morelli. 2005. Should yoghurt cultures be considered probiotic? Br. J. Nutr. 93:783-786.

Guillemard, E., F. Tondu, F. Lacoin, and J. Schrezenmeir. 2010. Consumption of a fermented dairy product containing the probiotic Lactobacillus casei DN-114001 reduces the duration of respiratory infections in the elderly in a randomised controlled trial. Br. J. Nutr. 103:58-68.

Hatakka, K., E. Savilahti, A. Pönkä, J. H. Meurman, T. Poussa, L. Näse, M. Saxelin, and R. Korpela. 2001. Effect of long term consumption of probiotic milk on infections in children attending day care centres: double blind, randomised trial. BMJ 322:1327.

Hiramatsu, Y., A. Hosono, T. Konno, Y. Nakanishi, M. Muto, A. Suyama, S. Hachimura, R. Sato, K. Takahashi, and S. Kaminogawa. 2011. Orally administered bifidobacterium triggers immune responses following capture by CD11c + cells in Peyer's patches and cecal patches. Cytotechnology 63:307-317.

Kadooka, Y., M. Sato, A. Ogawa, M. Miyoshi, H. Uenish, H. Ogawa, K. Ikuyama, M. Kagoshima, and T. Tsuchida. 2013. Effect of Lactobacillus gasseri SBT2055 in fermented milk on abdominal adiposity in adults in a randomised controlled trial. Br. J. Nutr. 110:1696-1703.

Kishimoto, M., R. Nomoto, and R. Osawa. 2015. In vitro evaluation of immunological properties of extracellular polysaccharides produced by Lactobacillus delbrueckii strains. Biosci. Microbiota Food Health 34:11-23.

Kitazawa, H., T. Harata, J. Uemura, T. Saito, T. Kaneko, and T. Itho. 1998. Phosphate group requirement for mitogenic activation of lymphocytes by an extracellular phosphopolysaccharide from Lactobacillus delbrueckii ssp. bulgaricus. Int. J. Food Microbiol. 40:169-175.

Leyer, G. J., S. Li, M. E. Mubasher, C. Reifer, and A. C. Ouwehand. 2009. Probiotic effects on cold and influenza-like symptom incidence and duration in children. Pediatrics 124:e172-e179.

Makino, S., S. Ikegami, H. Kano, T. Sashihara, H. Sugano, H. Horiuch, T. Saito, and M. Oda. 2006. Immunomodulatory effects of polysaccharides produced by Lactobacillus delbrueckii ssp. bulgaricus OLL1073R-1. J. Dairy Sci. 89:2873-2881.

Makino, S., S. Ikegami, A. Kume, H. Horiuch, H. Sasaki, and N. Orii. 2010. Reducing the risk of infection in the elderly by dietary intake of yoghurt fermented with Lactobacillus delbrueckii ssp. bulgaricus OLL1073R-1. Br. J. Nutr. 104:998-1006.

Merenstein, D., M. Murphy, A. Fokar, R. K. Hernandez, H. Park, H. Nsouli, M. E. Sanders, B. A. Davis, V. Niborski, F. Tondu, and N. M. Shara. 2010. Use of a fermented dairy probiotic drink containing Lactobacillus casei (DN-114 001) to decrease the rate of illness in kids: the DRINK study. A patient-oriented, double-blind, cluster-randomized, placebo-controlled, clinical trial. Eur. J. Clin. Nutr. 64:669-677.
Metchnikoff, E. 1907. The Prolongation of Life. William Heinemann, London, UK.

Michaylova, M., S. Minkova, K. Kimura, T. Sasaki, and K. Isawa. 2007. Isolation and characterization of Lactobacillus delbrueckii ssp. bulgaricus and Streptococcus thermophilus from plants in Bulgaria. FEMS Microbiol. Lett. 269:160-169.

Nagai, T., S. Makino, S. Ikegami, T. Itoh, and H. Yamada. 2011. Effects of oral administration of yogurt fermented with Lactobacillus delbrueckii ssp. bulgaricus OLL1073R-1 and its exopolysaccharides against influenza virus infection in mice. Int. Immunopharmacol. 11:2246-2250.

Nishimura-Uemura, J., H. Kitazawa, Y. Kawai, T. Itoh, M. Oda, and T. Saito. 2003. Functional alteration of murine macrophages stimulated with extracellular polysaccharides from Lactobacillus delbrueckii ssp. bulgaricus OLL1073R-1. Food Microbiol. 20:267-273.

O'Neill, L. A., and A. G. Bowie. 2007. The family of five: TIR-domaincontaining adaptors in Toll-like receptor signalling. Nat. Rev. Immunol. 7:353-364.

Okamura, H., S. Kashiwamura, H. Tsutui, T. Yoshimoto, and K. Nakanishi. 1998. Regulation of interferon- $\gamma$ production by IL-12 and IL-18. Curr. Opin. Immunol. 10:259-264.

Reid, G., J. Jass, M. T. Sebulsky, and J. K. McCormick. 2003. Potential uses of probiotics in clinical practice. Clin. Microbiol. Rev. $16: 658-672$.

Takeda, K., T. Kaisho, and S. Akira. 2003. Toll-like receptors. Annu. Rev. Immunol. 21:335-376.

Takeda, K., and K. Okumura. 2007. Effects of a fermented milk drink containing Lactobacillus casei strain Shirota on the human NK-cell activity. J. Nutr. 137:791S-793S.

Takeda, K., S. Seki, K. Ogasawara, R. Anzai, W. Hashimoto, K. Sugiura, M. Takahashi, M. Satoh, and K. Kumagai. 1996. Liver NK1.1+CD4 $+\alpha \beta$ T cells activated by IL-12 ad a major effector in inhibition of experimental tumor metastasis. J. Immunol. $156: 3366-3373$

Tillisch, K., J. Labus, L. Kilpatrick, Z. Jiang, J. Stains, B. Ebrat, D. Guyonnet, S. Legrain-Raspaud, B. Trotin, B. Naliboff, and E. A Mayer. 2013. Consumption of fermented milk product with probiotic modulates brain activity. Gastroenterology 144:1394-1401.

Tohno, M., T. Shimizu, W. Ueda, D. Anzawa, H. Aso, J. Nishimura, Y. Kawai, Y. Saito, T. Saito, and H. Kitazawa. 2007. Molecular cloning of porcine RP105/MD-1 involved in recognition of extracellular phosphopolysaccharides from Lactococcus lactis ssp. cremoris. Mol. Immunol. 44:2566-2577.

Trinchieri, G. 2003. Interleukin-12 and the regulation of innate resistance and adaptive immunity. Nat. Rev. Immunol. 3:133-146.

Watford, W. T., M. Moriguchi, A. Morinobu, and J. J. O'Shea. 2003. The biology of IL-12: Coordinating innate and adaptive immune responses. Cytokine Growth Factor Rev. 14:361-368.

Xiao, J. Z., S. Kondo, N. Yanagisawa, N. Takahashi, T. Odamaki, N. Iwabuchi, K. Miyaji, K. Iwatsuki, H. Togashi, K. Enomoto, and T. Enomoto. 2006. Probiotics in the treatment of Japanese cedar pollinosis: A double-blind placebo-controlled trial. Clin. Exp. Allergy 36:1425-1435.

Yuminamochi, E., T. Koike, K. Takeda, I. Horiuchi, and K. Okumura. 2007. Interleukin-12- and interferon- $\gamma$-mediated natural killer cell activation by Agaricus blazei Murill. Immunology 121:197-206. 